NRD -40

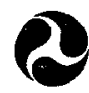

U.S.Department

of Transportation

National Highway

Traffic Safety

Administration

\title{
Recommended Child Safety Seat Enforcement Guidelines
}


The United States Guvernment does not endorse products or manufacturers. Trade or manufacturers' names appear only because they are considered essential to the object of this report. 
Technical Report Documentation Page

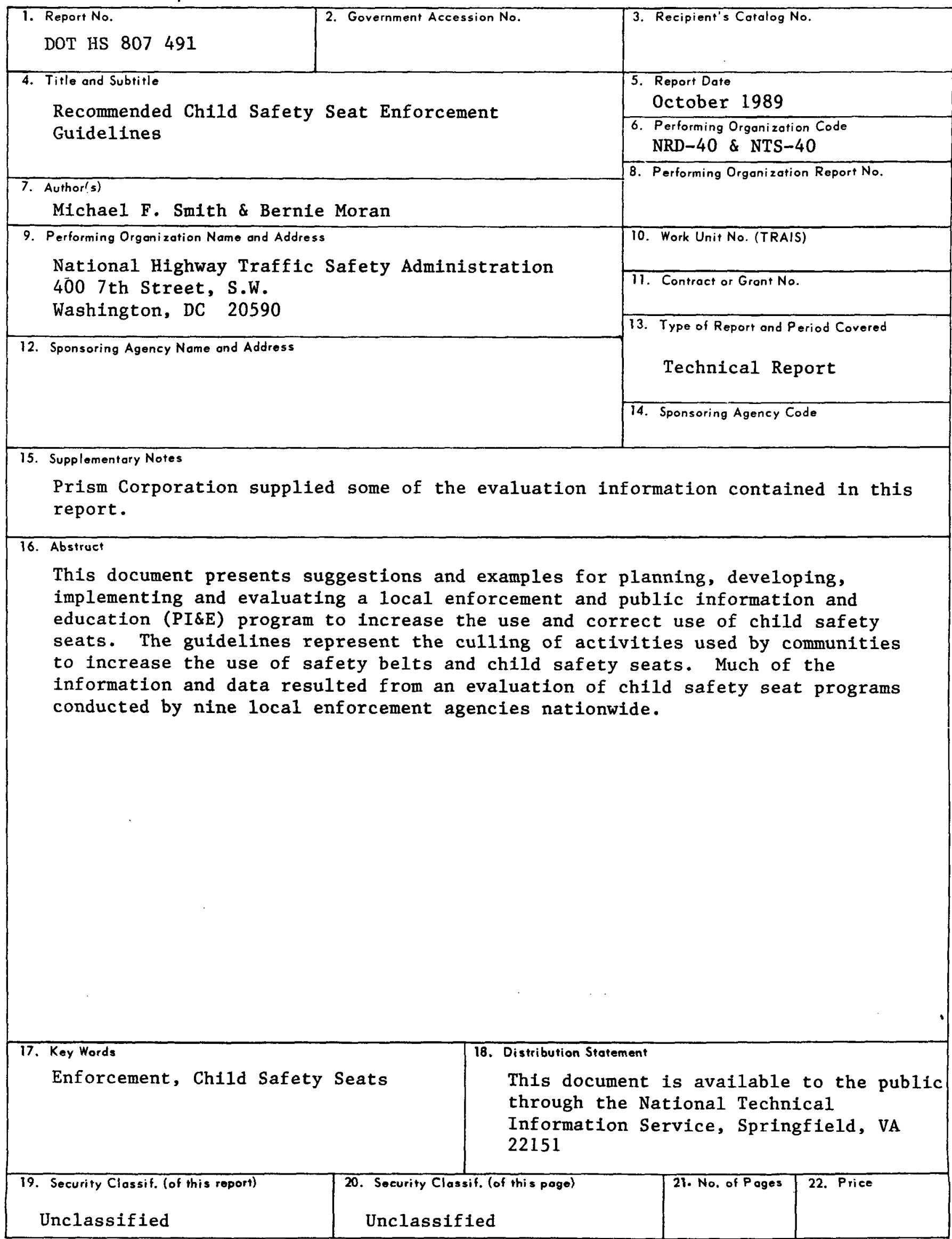




\section{RECOMMENDED CHILD SAFETY SEAT ENFORCEMENT GUIDELINES}

\section{Overview}

This document presents suggestions and examples for planning, developing, implementing and evaluating a local enforcement and public information and education (PI\&E) program to increase the use and correct use of child safety seats (CSS). The guidelines represent the culling of activities used by communities to increase the use of safety belts and child safety seats. Much of the information and data resulted from an evaluation by the National Highway Traffic Safety Administration (NHTSA) of child safety seat programs conducted by nine local enforcement agencies nationwide. For additional information on the evaluation of these nine programs, please see the final report, "Evaluation of Child Safety Seat Enforcement Strategies."

The guidelines are intended for use in planning and developing the most appropriate program for a particular community. However, the more effective programs include:

- Active enforcement.

- Integration of occupant protection enforcement into regular traffic safety enforcement - - an effective and efficient use of resources.

- Aggressive PI\&E to create and increase awareness of the enforcement efforts and the benefits of occupant protection in the community.

- Training members of the Police Department on the benefits of using occupant protection and enforcing occupant protection laws.

- Police Department policy requiring the use of safety belts in police vehicles.

- Community support -- including schools and local businesses.

By incorporating these components into a program and following the suggestions provided in these guidelines, states and localities can increase the use and correct use of child safety seats. 
The guidelines cover: the following elements needed for a successful program:

I. Identifying Problems and Opportunities

II. Developing Action Plans
A. Program goal and objectives
B. Activities needed to accomplish the objectives
C. Persons responsible for activities
D. Persons and organizations providing resources
E. Target audience(s)
F. Materials
G. Special Events
H. Schedule
I. Budget

III. Measuring and Evaluating Program Results

In addition, a listing of contacts for additional information and assistance is provided (see Attachment I).

\section{IDENTIFYING PROBLEMS AND OPPORTUNITIES}

The first step in developing an effective CSS program is to determine what specific problems the community faces and what opportunities can be capitalized on to help solve these problems. By identifying problems and opportunities, potential solutions can be determined, including the activities and resources the community will need for a program.

Examples of problem identification and opportunities are:

- The collection of accident data from the community or local area, especially if children who were not using CSS devices were involved. This data can be used to identify the need for a program, demonstrate the consequences of not using safety seats, and will form part of the data base used in evaluating program effects.

- In a community with a lower socioeconomic profile, parents may not be using child safety seats because of the cost of acquiring such 
equipment. A CSS loaner program could be instituted.

- For a community with a large older population, informational messages and materials encouraging grandparents to use child safety seats when their grandchildren visit would be appropriate.

- Members of the police force may not be knowledgeable about child safety seats and their correct installation and use. Offering occupant protection training for officers could be an effective activity.

Problem identification requires the program developer to know and understand the occupant protection law(s), the community, current use patterns, resources available for conducting enforcement and PI\&E campaigns, and the likely

results. For example, if patrol officers are not required to use safety belts on duty, then a policy should be instituted. Under such a policy, the enforcement program has greater credibility with the general public. Or, if the community has not focused on child safety seat use previously, there is usually a good opportunity to conduct an awareness campaign. By taking advantage of circumstances and opportunities, communities can greatly increase the chances of a program being effective.

\section{DEVELOPING ACTION PLANS}

The second major step in establishing an effective program is to develop an Action Plan. The plan will identify who is doing what, for what reason, and how they are doing it. The Plan should include the following information:

- Program goal and objective(s)

o Activities needed to accomplish the objectives

- Persons responsible for the activities

- Persons and organizations providing resources (people, money, materials, etc.)

- Target audience(s)

- Materials

- $\quad$ Special events

- Schedule

- Budget 


\section{A. Program Goal \& Objectives}

Successful programs have a clearly stated goal and specific objectives. The goal is an overa1l. statement of program intent. objectives more clearly define the goal of the program. Objectives help determine the program direction, activities, target audience, period of time for the activities, and the expected results. Objectives also identify what is to be measured to assure that the objectives have been met.

The objectives also can help identify slogans and titles that can be useful to the program. For example, the slogan "Buckle up. Your child and you." helps support a campaign targeted primarily to parents. The slogan "Don't risk it - Click it!" helps communicate a dual message about enforcement and safety.

Example objectives for PI\&E and enforcement components of a program are provided in the following subsections.

Public Information and Education Component. Public information and education with regard to occupant protection can take many forms. This includes public service advertisements (PSAs) for radio, television and print media, exhibits at public events such as parades and county fairs, speaking engagements at organizational and school meetings, and the distribution of booklets, pamphlets, and fact sheets.

The PI\&E should be initiated before the start of the increased enforcement and continued on a periodic basis throughout the program. Important topics to be included are; a detailed description of the occupant protection restraint laws being enforced, the benefits of using occupant protection restraints correctly, the possibility of tragic results when unrestrained occupants are involved in a crash, and a description of the city's occupant safety promotion program and the person(s) involved.

Because safety belts and child safety seats are relevant to many audiences, the use of mass media is appropriate for community programs. Mass media approaches usually involve public service advertisements (PSAs), editorials, fact sheets (such as death/injury statistics), feature stories and articles, talk shows, and news releases (whether occupant protection devices were used in a traffic crash and the consequences).

Materials should be prepared for both the printed media (daily and weekly newspapers, magazines) and for the broadcast media (radio and television, including cable television). Many stations will air supportive messages such as "remember to buckle up" after a traffic report. Although most programs use only public service or "free" advertising, budgets can contain funds (local or community) for paid advertising.

PI\&E also can be developed for special audiences. For example, grandparents can be targeted to receive messages about the importance of keeping their visiting grandchildren safe in motor vehicles. Lower socioeconomic families can be targeted to receive information on CSS loaner programs. 
Community programs often include one or more news conferences to announce the launching of a program, continuance of a program, or a program's success. Community leaders should be encouraged to publicly support the program, the efforts of the police, and those of others who have played major roles in the program. Local broadcast stations often are willing to produce PSAs using local officials. They also will use PSAs produced by national organizations and government agencies, especially if local tags can be used. Many stations will even provide local tagging services.

Examples of PI\&E objectives are:

- Increase community awareness about the benefits of using occupant protection devices and that the law(s) are being enforced (e.g., 308 to 608 in six months).

- Educate the public about the benefits of correct use of child safety seats.

- Inform the public about a specific enforcement effort or blitz, including results (e.g., number of citations).

- Inform the public about a child safety seat loaner program.

- Run community-oriented education activities whereby patrol officers visit schools and speak about occupant protection and other traffic safety topics (e.g., reach 2,000 children over 12 months).

- Use of police spokespersons for mass media activities, including interview shows and PSAs.

- Encourage local employers, including government agencies, to establish and enforce occupant protection policies for employees while in company vehicles, and encourage the use of occupant protection devices while in their private vehicles (e.g., get three major employers to cooperate).

- Encourage employers to disseminate materials about occupant protection, including child safety seats (e.g., get 10 major employers to cooperate).

- Establish a child safety seat loaner program (e.g., 50 seats on loan). Many communities have found a CSS loaner program to have two benefits - as a way to create awareness about CSS in general and as a means of encouraging lower income families to use CSS.

Enforcement Component. A program to encourage the use of child safety seats and safety belts would incorporate an enforcement component. This component includes the training of police officers in the benefits of using 
occupant protection, strategies to use in actually enforcing the law(s), and safety belt use policies for police officers. One available training program that covers these issies was developed by the International Association of Chiefs of Police and NHTSA - "Occupant Protection Usage and Enforcement."

Training can include the showing of a film or videotape and may be presented in special sessions or as part of ongoing, in-service training. More effective training-oriented programs have permenent trainers and include follow-up or refresher programs given to as many members of the police department as possible. Even if the program planner uses an existing occupant protection training course, they still must plan on how to train all members of the department, the form(s) of training (in-service, workshops presented by the department, or seminars conducted by other organizations), and the particular procedures to use in the initial and follow-up training (videotapes, role playing, discussions, demonstrations, etc.).

The enforcement component also should encompass ways to recognize police personnel. For example, a "Saved by the Belt" club can be formed for officers who have been saved by using a safety belt. Letters of citation and appreciation can be sent to officers who support and/or participate in the program. Internal communication activities, including bulletins, paycheck stuffers and role calls, can help emphasize the importance of police support and participation in a CSS enforcement program.

There are several important enforcement strategies that should be used by the police. Incorporation of occupant protection law enforcement into regular traffic safety enforcement duties and as a part of other special enforcement efforts (e.g., DWI, speed control, roadblocks) is the most important. However, special occupant protection enforcement activities also can be conducted. Special enforcement should be based on the target audience so that enforcement activities are focused on the places and times of day when the greatest impact will be realized. For example, CSS enforcement can be concentrated during the hours when children are mostly likely to be in vehicles (opening and closing hours of school) and where these vehicles are mostly likely to be (schools, shopping centers).

Examples of enforcement objectives are:

- Increase use of child safety seats (e.g., from 408 to 608 in 12 months).

- Increase correct use of child safety seats (e.g., from $60 \%$ to $80 \%$ in 12 months).

- Increase general compliance with occupant protection laws.

- Increase the number of citations and warnings for violation of occupant protection laws (e.g., from 2 per week to 10 per week). 

belts in official vehicles (e.g., obtain $90 \%$ use in six months).

- Provide a statement of support for the Departmental Policy and increased enforcement of the occupant protection laws by the Chief, Superintendent, or Sheriff.

- Establish training programs to educate patrol officers about the law, agency use policies, and the use and correct use of safety belts and child restraints.

- Incorporation of occupant protection law enforcement into regular traffic duties and combined with other special enforcement efforts (DUI, speed).

- Special occupant protection enforcement activities.

- Provide training for neighboring Police Departments.

- Have officers hand out information at traffic stops on safety belts, cSs devices, and automatic restraints.

\section{Persons Responsible for the Activities}

A specific person should be charged with responsibility for the program. This person should be part of the police department, but if they are not, they must establish a strong cooperative working relationship with the police. If funding permits, administrative support should be obtained. The program manager should be responsible for involving others, setting objectives, developing action plans, implementing the plans, monitoring activities, and evaluating the program's effectiveness.

Although one person should be in charge of the overall program and should serve as the major spokesperson for the program, many people are needed to accomplish the various specific objectives and activities. For example, patrol officers to enforce the $\mathrm{law}(\mathrm{s})$ and present occupant protection information to the public; teachers or other volunteers to distribute guidelines for poster/essay contests; students to conduct observational studies; volunteers to staff informational exhibits; even people to dress up in Vince and Larry costumes.

\section{Persons and Organizations Providing Resources}

The plan should specify the resources to be used throughout the program, including people, materials, in-kind contributions, money, etc. The human resources should be defined in terms of technical and administrative responsibilities as well as paid and volunteer positions. Also, an important 
part of many programs is specifying what work is to be performed on a overtime or donated basis. Overtime hours for police officials, for example, should be accounted for in the budget.

The most successful programs represent team efforts. There are many organizations with a common interest in the safety of a community's children. The following are examples of organizations that could provide support and resources.

- Child safety seat and safety belt coalitions and organizations

- Schools and school-related groups

- Hospitals, other doctor, nurse, and EMS technician groups, and other health-related organizations and associations

- Commercial retailers, especially those that cater to families with young children (fast-food restaurants)

- Volunteer organizations involved in traffic safety

- Insurance companies

- Local government

- Other community groups such as local Chamber of Commerce

These organizations and groups can provide direct and indirect support, including funding, materials, and personnel. Examples are:

- Businesses can give incentives such as meal coupons to be used as rewards and distribute materials.

- Other consumer-oriented organizations such as the American Automobile Association can provide materials.

- State and national organizations can supply publications and specialty items.

- Local radio and television stations can produce PSAs for distribution to others.

- Child safety seat and safety belt coalitions can provide funding and materials.

- PTA, Chambers of Commerce, even city governments can provide funding, facilities, materials, and personnel. 
- Special groups and associations can reprint materials or provide other support for the program.

- Students can conduct observations of CSS and safety belt use before and after the program as part of the evaluation effort.

- Volunteers can dress up as safety characters for exhibits and parades.

- Volunteers can distribute information at special events and activities.

- Utilities can incorporate occupant protection messages in monthly bills.

- Youth organizations such as the Scouts can sponsor activities, provide volunteers, and require their members be buckled up when going on official trips.

- Hospitals and medical clinics can have displays and distribute information, request that all children be in occupant protection device when leaving, offer occupant protection education programs to staff, and soon-to-be and new parents.

\section{E. Target Audiences}

An important element in carrying out a successful program is delivering the appropriate message(s) to the appropriate audience(s). Thus, a good action plan specifies the target audiences. A program can seek to reach one or more audiences, depending on the resources available. Once an audience is targeted, decisions can be made about the appropriate media channel(s) and times for delivering the message. For example, programs targeted to children can include developing PSAs for radio and TV programs airing during the hours when more children are likely to be listening/viewing. To reach grandparents, informational materials and programs can be given at senior citizen and retirement centers.

Audiences can include:

- General public

- Licensed drivers

- Parents/grandparents

- Children

- Teenagers 

- Enforcement community
- School personnel
- Organizations serving children (PTA, Boy Scouts)
- Medical personnel and institutions (pediatricians, hospitals)

\section{F. Materials}

An important part of a program is information presented in print and audiovisual form. Most programs involve the distribution of fact sheets, flyers, posters, brochures and other information in print form. Educational programs, especially those directed to schools and enforcement personnel, also use films and videotapes. Many times, usable materials are available from state, regional and national resources.

Materials can include a wide variety of specialty items. Some examples are; bumper stickers, buttons, coloring books, certificates (for safety belt use), reminder cards, bibs, t-shirts, and coffee mugs.

\section{G. Special Events}

Because the programs are planned and carried out at the local level, there are many opportunities for special events and activities. These efforts can be directly related to the program or incorporated into other scheduled community events. They can be local or tied to national efforts. They can range from a speaker's bureau where Officer Friendly talks with school children to essay contests to costumed Vince and Larry characters. Special events and activities include the following:

- Use of characters such as McGruff the crime prevention dog, Vince and Larry, Officer Friendly, Sgt. Safety.

- Tie in with national events such as National Child Passenger Safety Awareness Week and Buckle Up America Week or with local, state or regional activities such as "Safety Day."

- Seasonal events such as county fairs, holiday parades.

- Program messages incorporated into mass mailings such as water bills.

- Exhibits/informational booths/displays at events drawing large numbers of people (Senior Citizen's Fair, County Fair), or at local shopping malls. 

donated).

- Participation in parades, using costumed characters, distributing materials and using specialty items such as buttons and balloons, and displaying the message/slogan.

- Establishment of a "Saved by the Belt" club to recognize people who have been saved by using a belt.

\section{H. Schedule}

Every action plan should have a schedule. Program start and end dates should be identified along with dates and timetables for all major activities associated with the program. The program should be conducted over extended time periods ( 12 months) to maximize its effectiveness. With planning, the program can become integrated into a community's on-going activities.

\section{Budget}

The budget for any program, at a minimum, should include funding sources and a listing of all major expenses. Examples of budget items includes: personnel services (project manager), training, enforcement and/or special duty, secretarial, local exhibits and presentations, materials, specialty items, publications and printing (decals, balloons, posters, brochures, booklets, coloring books), videotapes, CSS devices (loaner program), and program evaluation. Many of the programs from which these guidelines were devised were conducted with small amounts of money. For example, funding included $\$ 5,000$ grants from NHTSA, direct financial support from other government and private sector organizations, and in-kind contributions of people, facilities, and materials.

\section{MEASURING AND EVALUATING PROGRAM RESULTS}

The final component of any program should be a provision for measuring and evaluating results. Ideally there would be an observational survey to determine how many children and adults were using occupant protection devices, and using them correctly, before the program is started and then again after the program ends. If the program is to run for an extended period (12 months or more), observations also should be done one or more times during the program to determine how well the program is doing. There are other measures that also should be used to determine the result of a program, including:

- Number of officers trained

- Number of officers using safety belts 
- Number of occupant protection citations and convictions

- Number of child safety seats loaned

- Number of presentations

- Number of informational materials distributed

- Number of newspaper articles published

- Amount of TV and radio airtime

- Number of target audience members reached

- Change in awareness and knowledge about occupant protection laws and issue:s (obtained through surveys)

- Change in injuries resulting from traffic crashes

\section{SOURCES OF ADDITIONAJ, INFORMATION}

This document has presented suggestions for planning, developing, implementing and evaluating child safety seat enforcement programs. There are many additional sources of information about child safety seat (and occupant protection) programs and related topics. Some state and national sources are listed in Attachment I. Many of these contacts also can provide resources for your program. 


\section{GOVERNORS' HIGHWAY SAFETY REPRESENTATIVES}

In each State there is an Office of Highway Safety headed by a Highway Safety Representative appointed by the Governor. The Governor's Highway Safety Representative manages the State/Federal Highway Safety Grant Program that funds a wide variety of programs aimed at reducing fatalities and injuries on the nation's highways. Each Governor's Representative can provide materials and information about particular State projects and programs designed to accomplish this goal and about special activities.

\section{ALABAMA}

Governor's Highway Safety Representative AL Department of Economic \& Community Affairs

P.O. Box 2939

3465 Norman Bridge Road

Montgomery, AL 36105-0939

(205) 261-3572

\section{ALASKA}

Governor's Highway Safety Representative Highway Safety Planning Ágency

Department of Public Safety

P.O. Box N

450 Whittier Street

Juneau, AK 99811

(907) 465-4300

\section{AMERICAN SAMOA}

Governor's Highway Safety Representative American Samoa Government

P.O. Box 1086

Pago Pago, American Samoa 96799

(684) 633-1111

(Through International Operator)

\section{ARIZONA}

Governor's Highway Safety Representative Governor's Office of Highway Safety

3010 N. Second Street, Suite 105

Phoenix, AZ 85004

(602) 255-3216

\section{ARKANSAS}

Governor's Highway Safety Representative Transportation Safety Agency

Justice Building, Suite 100

Little Rock, AR 72201

(501) 682-1341

\section{CALIFORNIA}

Governor's Highway Safety Representative Office of Traffic Safety

Business and Transportation Agency

7000 Franklin Boulevard, Suite 330

Sacramento, CA 95823

(916) 445-0527

\section{COLORADO}

Governor's Highway Safety Representative Director, Division of Highway Safety

4201 East Arkansas Avenue

Denver, CO 80222

(303) 757-9452

\section{CONNECTICUT}

Governor's Highway Safety Representative Department of Transportation

Bureau of Highways

24 Wolcott Hill Road

Wethersfield, CT 06109

(203) 666-4343 


\section{DELAWARE}

Governor's Highway Safety Representative

Office of Highway Safety

Thomas Collins Building, Suite 363

540 S. DuPont Highway

Dover, DE 19901

(302) $736-4475$

\section{DISTRICT OF COLUMEIA}

Governor's Highway Safety Representative

Department of Public Works

Frank D. Reeves Center

2000-14th Street, NW, 6th floor

Washington, DC 20009

(202) 939-8000

\section{FLORIDA}

Department of Community Affairs

Governor's Highway Safety Representative 2740 Center View Drive

Tallahassee, FL 32399-2100

(904) 488-8466

\section{GEORGIA}

Governor's Highway Safety Representative Office of Highway Safety

The Equitable Building

100 Peachtree Street, Ste. 2000

Atlanta, GA 30303

(404) 656-6996

\section{GUAM}

Governor's Highway Safety Representative Department of Public Works, OHS

P.O. Box 2950

Agana, GU 96910

(671) 646-8643

(Through International Operator)

\section{HAWAII}

Governor's Highway Safety Representative Department of Transportation 869 Punchbowl Street

Honolulu, HI 96813

(808) 548-4655

\section{DAHO}

Governor's Highway Safety Representative Idaho Department of Transportation

P.O. Box 7129

3311 West State Street

Boise, ID 83707

(208) 334-8101

\section{ILLINOIS}

Governor's Highway Safety Representative Division of Traffic Safety

319 Administration Building

2300 South Dirkson Parkway

Springfield, IL 62764

(217) $782-4972$

\section{INDIANA}

Governor's Highway Safety Representative State Capitol - Room 210

Indianapolis, IN 46204

(317) $232-4578$

\section{IOWA}

Governor's Highway Safety Representative Iowa Department of Public Safety

Wallace State Office Building

Des Moines, IA 50319

(515) 281-5261

\section{KANSAS}

Governor's Highway Safety Representative Kansas Department of Transportation State Office Building

Topeka, KS 66612

(913) 296-3461

\section{KENTUCKY}

Governor's Highway Safety Representative Kentucky State Police Headquarters

919 Versailles Road

Frankfort, KY 40601-9980

(502) 695-6300 


\section{LOUISIANA}

Governor's Highway Safety Representative Louisiana Highway Safety Commission Department of Public Safety P.O. Box 66336, Capitol Station Baton Rouge, LA 70896

(504) 925-6991

\section{MAINE}

Governor's Highway Safety Representative Bureau of Safety Department of Public Safety

Northem Avenue

Gardner, ME 04345

(207) 582-8776

\section{MARYLAND}

Governor's Highway Safety Representative Department of Transportation

P.O. Box 8755

Baltimore-Washington

International Airport

Baltimore, MD 21240-0755

(301) 859-7397

\section{MASSACHUSETTS}

Governor's Highway Safety Representative 100 Cambridge Street

Saltonstall State Office Bldg., Rm. 2104

Boston, MA 02202

(617) 727-5073

\section{MICHIGAN}

Governor's Highway Safety Representative Office of Highway Safety Planning 300 Washington Square, Suite 300

Lansing, MI 48913

(517) 334-7908

\section{MINNESOTA}

Governor's Highway Safety Representative Department of Public Safety

Transportation Building, Rm. 207

St. Paul, MN 55155

(612) 296-6642

\section{MISSISSIPPI}

Governor's Highway Safety Representative Office of Highway Safety

301 West Pearl Street

Jackson, MS 39203-3085

(601) 949-2198

\section{MISSOURI}

Governor's Highway Safety Representative Division of Highway Safety

Department of Public Safety

P.O. Box 1406

Jefferson City, MO 65102-1406

(314) $751-4161$

\section{MONTANA}

Governor's Highway Safety Representative Highway Traffic Safety Division

Department of Justice

303 North Roberts

Helena, MT 59620

(406) 444-3412

\section{NEBRASKA}

Governor's Highway Safety Representative Department of Motor Vehicles

P.O. Box 94789

301 Centennial Mall South

Lincoln, NE 68509-4789

(402) 471-2281

\section{NEVADA}

Governor's Highway Safety Representative Department of Motor Vehicles

555 Wright Way, Room 258

Carson City, NV 89711-0999

(702) 885-5375

\section{NEW HAMPSHIRE}

Governor's Highway Safety Representative New Hampshire Highway Safety Agency 117 Manchester Street

Concord, NH 03301

(603) $271-2131$ 
NEW JERSEY

Governor's Highway Safety Representative

Office of Highway Traffic Safety

Department of Law and Public Safety

Quakerbridge Plaza, Bldg. \#5, CN-048

Trenton, NJ 08625

(609) 588-3750

NEW MEXICO

Governor's Highway Safety Representative Department of Highways and Transportation P.O. Box 1149

Santa Fe, NM 87504-1149

(505) 827-5110

\section{NEW YORK}

Governor's Highway Safety Representative New York Department of Motor Vehicles

Empire State Plaza

Swan Street Building

Albany, NY 12228

(518) 474-0841

\section{NORTH CAROLINA}

Governor's Highway Safety Representative 215 East Lane Street

Raleigh, NC 27601

(919) 733-3083

\section{NORTH DAKOTA}

Governor's Highway Safety Representative North Dakota Highway Department 600 East Boulevard Avenue Bismarck, ND 58505-0178

(701) 224-2581

\section{COMMONWEALTH OF THE NORTHERN MARIANA ISLANDS}

Governor's Highway Safety Representative

Department of Public Safety

Commonwealth of the Northem

Mariana Islands

Saipan, Northern Mariana Islands 96950

(670) 234-6333 or 6431

(Through International Operator)

\section{OHIO}

Governor's Highway Safety Representative

Department of Highway Safety

P.O. Box 7167

240 Parsons Avenue

Columbus, $\mathrm{OH} 43205$

(614) $466-2550$ or 3383

\section{OKLAHOMA}

Governor's Highway Safety

Representative

Oklahoma Dept. of Transportation

200 NE 21st Street

Oklahoma City, OK 73105

(405) 521-3314

\section{OREGON}

Governor's Highway Safety Representative Oregon Traffic Safety Commission

State Library Building-4th Floor

Salem, OR 97310

(503) $378-3670$ or 3669

\section{PENNSYLVANIA}

Governor's Highway Safety Representative Department of Safety Administration 1200 Transportation \& Safety Building

Harrisburg, PA 17120

(717) 787-3928

\section{PUERTO RICO}

Governor's Highway Safety Representative Department of Transportation and Public Works P.O. Box 41269, Minillas Station

Santurce, PR 00940

(809) 726-6670

\section{RHODE ISLAND}

Governor's Highway Safety Representative Department of Transportation

State Office Building - Smith Street

Providence, RI 02903

(401) 277-2481 


\section{SOUTH CAROLINA}

Governor's Highway Safety Representative Office of Highway Safety Programs

Edgar A. Brown State Office Bldg. 1205 Pendleton Street, Room 453

Columbia, SC 29201

(803) 734-0421

\section{SOUTH DAKOTA}

Governor's Highway Safety Representative Department of Commerce and Regulation 910 East Sioux Avenue

Pierre, SD 57501

(605) 773-3178

\section{TENNESSEE}

Governor's Highway Safety Representative Department of Transportation James K. Polk State Office Building 505 Deaderick Street, Suite 700

Nashville, TN 37219

(615) 741-2848

\section{TEXAS}

Governor's Highway Safety Representative State Department of Highways and Public Transportation

11 th and Brazos

Austin, TX 78701

(512) $463-8616$

\section{UTAH}

Governor's Highway Safety

Representative

Department of Public Safety

4501 South 2700 West

Salt Lake City, UT 84119

(801) 965-4461

\section{VERMONT}

Governor's Highway Safety Representative Department of Transportation

133 State Street

Montpelier, VT 05602

(802) 828-2657

\section{VIRGINIA}

Governor's Highway Safety Representative Department of Motor Vehicles

P.O. Box 27412

Richmond, VA 23269

(804) 367-6602

\section{VIRGIN ISLANDS}

Governor's Highway Safety Representative Virgin Island Office of Highway Safety Lagoon Street Complex

Building \#2, Rm. 218

Fredricksted, St. Croix, VI 00840

(809) $772-5820$

\section{WASHIINGTON}

Governor's Highway Safety Representative Washington Traffic Safety Commission 1000 S. Cherry Street, MS/PD-11

Olympia, WA 98504

(206) 753-6197

\section{WEST VIRGINIA}

Governor's Highway Safety Representative Criminal Justice and Highway Safety Office 5790-A MacCorkle Avenue

Charleston, WV 25304

(304) 348-8814

\section{WISCONSIN}

Governor's Highway Safety Representative Wisconsin Office of Highway Safety P.O. Box 7910

4802 Sheboygan Avenue

Madison, WI 53707

(608) 266-1113

\section{WYOMING}

Governor's Highway Safety Representative Wyoming Highway Department

Highway Safety Branch

P.O. Box 1708

Cheyenne, WY 82002-9019

(307) 777-7296 


\section{NATIONAL HIGHWAY TRAFPIC SAFETY ADMINISTRATION (NHTSA) REGIONAL OFFICES}

Region I:

(Connecticut, Maine, Massachusetts, New Hampshire, Rhode Island, Vermont) NHTSA

Transportation Systems Center

Kendall Square Code 903

Cambridge, MA 02142

(617) 494-3427

\section{Region II:}

(New Jersey, New York, Puerto Rico, Virgin (slands)

NHTSA

Room 204

222 Mamaroneck Avenue

White Plains, NY 10605

(914) 683-9690

\section{Region III:}

(Delaware, District of Columbia, Maryland, Pennsylvania,

Virginia, West Virginia)

NHTSA

BWI Commerce Park

7526 Connelley Drive, Suite L

Hanover, MD 21076-1699

(301) 768-7111

\section{Region IV:}

(Alabama, Florida, Georgia, Kentucky, Mississippi, North Carolina,

South Carolina, Tennessee)

NHTSA

Suite 501

1720 Peachtree Road, N.W.

Atlanta, GA 30309

(404) $347-4537$

\section{Region V:}

(Illinois, Indiana, Michigan,

Minnesota, Ohio, Wisconsin)

NHTSA

18209 Dixie Highway

Homewood, IL 60430

(312) 799-6067
Region VI:

(Arkansas, Louisiana, New Mexico, Oklahoma, Texas)

NHTSA

819 Taylor Street

Room 8A38

Fort Worth, TX 76102-6177

(817) $334-4300$

\section{Region VII:}

(Iowa, Kansas, Missouri, Nebraska)

NHTSA

P.O. Box 412515

Kansas City, MO 64141

(816) 926-7887

Region VIII:

(Colorado, Montana, North Dakota, South Dakota, Utah, Wyoming)

NHTSA

555 Zang Street, 4th Floor

Denver, CO 80228

(303) 236-3444

\section{Region IX:}

(American Samoa, Arizona, California,

Guam, Hawaii, Nevada)

NHTSA

211 Main Street

Suite 1000

San Francisco, CA 94105

(415) $974-9840$

Region X:

(Alaska, Idaho, Oregon, Washington)

NHTSA

3140 Jackson Federal Building

915 Second Avenue

Seattle, WA 98174

(206) 442-5934 
INTERNATIONAL ASSOCIATION OF CHIEFS OF POLICE

1110 North Glebe Road

Arlington, VA 22201

(703) $243-6500$

NATIONAL SHERIFF'S ASSOCIATION

1450 Duke Street

Alexandria, VA 22314

(703) $836-7827$

DIVISION OF POLICE TRAFFIC SERVICES, NTS-41

Office of Enforcement \& Emergency Services

National Highway Traffic Safety Administration

4007 th Street, S.W.

Washington, D.C. 20590

(202) 366-4295

PROGRAM DEVELOPMENT \& PLANNING DIVISION, NTS-13

Office of Occupant Protection

National Highway Traffic Safety Administration 4007 th Street, S.W.

Washington, D.C. 20590

(202) 366-2711 